JHR

32,5

334

Received 17 January 2018 Accepted 26 March 2018

\section{Can early initiation to breastfeeding prevent stunting in 6-59 months old children?}

\author{
Muldiasman, Kusharisupeni and Endang Laksminingsih \\ Department of Public Health Nutrition, Faculty of Public Health, \\ University of Indonesia, Jakarta, Indonesia, and \\ Besral \\ Department of Biostatistics, Faculty of Public Health, \\ University of Indonesia, Jakarta, Indonesia
}

\begin{abstract}
Purpose - The prevalence of stunting in children under five years old is high (37.9 percent). The health advantage of breast milk as a prevention is recognized. The purpose of this paper is to examine the relationship of early initiation to breastfeeding, wherein a child is breastfed within an hour of birth, as a means of preventing stunted growth in 6-59 month old children in Jambi province, Indonesia.

Design/methodology/approach - This paper used data from the 2015 National Nutrition Survey in Jambi province. A total of 2,502 children aged 6-59 months were analyzed by binary logistic regression.

Findings - The results showed that as many as 27.5 percent (95\% CI: 25.2-29.9) children aged 6-59 months were stunted and 54.1 percent (95\% CI: 51.1-57.1) had not been introduced to breastfeeding soon after birth. The analysis showed that delayed initiation to breastfeeding is a significant factor in stunting amongst 6-59 month old children. ( $p=0.024 ; \mathrm{AOR}=1.3 ; 95 \% \mathrm{CI}$ : 1.0-1.6). Other results of the analysis showed a significant association between water source and birth weight issues as causes for stunting.

Originality/value - Research revealed that delayed initiation into breastfeeding results in a 1.3 times higher risk of stunting. Furthermore, early initiation to breastfeeding reduces the risk of consuming polluted river water that is a health risk and cause of stunting.
\end{abstract}

Keywords Indonesia, Breastfeeding, Early initiation to breastfeeding, Stunting in children

Paper type Research paper

\section{Introduction}

The purpose of this study was to determine the relationship between early initiation to breastfeeding with stunting in children 6-59 months. Stunting in children under five years is a global problem, mainly experienced in developing countries. The results of a joint UNICEF, World Health Organization (WHO) and World Bank analysis of 142 national survey results of poor and developing countries, found that in 2011, stunting prevalence affected 165 million children with an estimated 127 million children under five projected to be stunted by 2025[1,2]. Stunting in under-five children is a problem in Indonesia where basic health research (Riskesdas) revealed the high prevalence of stunting in under fives in 2007, 2010 and 2013 by 36.8, 35.6 and 37.2 percent[3-5]. Jambi Province has a stunting problem greater than the national average by 37.9 percent[5].

Stunting creates a barrier to the forming and development of organs and has a short term impact on mortality, morbidity and disability. Long term consequences include negative

(c) Muldiasman, Kusharisupeni, Endang Laksminingsih and Besral. Published in Journal of Health Research. Published by Emerald Publishing Limited. This article is published under the Creative Commons Attribution (CC BY 4.0) licence. Anyone may reproduce, distribute, translate and create derivative works of this article (for both commercial and non-commercial purposes), subject to full attribution to the original publication and authors. The full terms of this licence may be seen at http://creativecommons.org/licences/ by/4.0/legalcode

The authors thank the Jambi Provincial Health Office for permission to use data. 
impacts on adult body size, intellectual ability, economic productivity, reproductive ability and metabolic and blood vessel disease $[1,6,7]$.

Diarrhea, cough, cold, fever, shortness of breath, are associated with stunting in children under five[8] and is a proven risk of respiratory tract infection by four times[9]. The risk of stunting increases based on an unhealthy source of drinking water[10] and poor sanitation facilities[11, 12]. Low participation in basic community heath checks is another risk factor of stunting in urban areas[13].

Early initiation to breastfeeding, exclusive breastfeeding, duration of breastfeeding, and vitamin A administration are associated with preventing stunting in children under five years of age. Previous research indicates an exclusive breastfeeding relationship with stunting $[14,15]$ and a relationship between supplementation to breast feeding during the first four months $(p=0.04)$ with stunting in children[16].

\section{Methods}

Data from the National Nutrition Survey in Jambi province in 2015 were studied. Data were collected through Nutrition Status Monitoring Activities using a cross-sectional design including questionnaires, interviews and observations. The status of exposure and disease were observed simultaneously in individuals over the same period between September and October 2015.

The research location was Jambi Province, Indonesia consisting of ten districts/cities. In total, 30 clusters were selected from each district and city. In each cluster ten households were selected as the sample.

The population of this study was all children aged 6-59 months in Jambi province. The sample criteria included the following: child's birth date is known, the child is weighed at birth and during observation, the child's length is measured at birth and during observation, the determinant of stunting questionnaire in the child is complete.

The selection of clusters in districts and cities is systematically randomized based on probability proportional to size. The nutritional status used was collected by looking at birth records, viewing $\mathrm{MCH}$ books, interviews with toddlers and field observations. Stunting is measured anthropometrically according to WHO standards 2005.

Data collection was conducted by graduates of the Nursing and Midwifery Academy. There were six people in each District/City and two field supervisors. The Data collector and supervisor team attended three days training on September 18-20, 2015. Training materials comprised: nutrition program policies, sampling methods, interview techniques, anthropometric measurements, questionnaire content and field practice.

Univariate analysis was performed to provide a stunting prevalence picture in children 6-59 months, early initiation to breastfeeding and other variables. The bivariate analysis was conducted to find out the association of each independent variable with stunting variable in children 6-59 months. Multivariate analysis was conducted to see the relationship of early initiation to breastfeeding with stunting in children 6-59 months. Analysis was done by binary logistic regression for survey data.

\section{Results}

Stunting in children 6-59 months

A total of 27.5 percent (95\% CI: 25.2-29.9) children aged 6-59 months are stunted in Jambi province, Indonesia, in 2015.

\section{Early initiation to breastfeeding and child characteristics 6-59 months}

Most children of 6-59 months do not get the opportunity to breastfeed early (54.1 percent; 95\% CI: 51.1-57.1) with irregular visits to community base health services/posyandu (44 percent). The number of boys (52 percent) is almost the same as girls (48 percent). 
JHR

32,5

336

A small number of them do not have good sanitation facilities (14 percent). Some of them are not exclusively breastfed (41 percent). A small number of them have a history of diarrhea in the last one month (15 percent). Over a third of them had a history of cough (38 percent), cold (45 percent), fever (35 percent) in the last one month. A small number of them do not boil drinking water (13 percent). Most of them live in rural areas (74 percent). Father and mother ethnicity is predominantly, non native or "The Outsider" (41 percent) and Mixed (12 percent). Some of them have well water as a source of drinking water (57 percent). A few (3 percent) of their families have an inadequate quality source of drinking water (cloudy/smelly/tasty/colorful). A small number of them have poorly structured homes (3 percent). A small number of them have a large number of household members (18 percent). Fathers education (53 percent) and mothers education (55 percent) are basic. A minority of fathers jobs are "not fixed and others" (15 percent) while a small portion of mothers (21 percent) are working. Few of them weigh less than 2,500 gram (3 percent). More than a quarter of them had a birth length of less than $48 \mathrm{~cm}$ (27 percent) (Table I).

Other results of the analysis showed a significant association between water source and birth weights to stunting (Table II). The most dominant risk factor for stunting was age 24-59 months with a risk 2.5 times higher than the age of 6-11 months $(p=0.000$; $\mathrm{AOR}=2.5 ;$ 95\% CI: 1.8-3.6).

\section{Discussion}

Stunting in children 6-59 months

Based on the research results, it is known that 27.5 percent (95\% CI: 25.2-29.9) of children aged 6-59 months were stunted in Jambi province in 2015. This is lower than 2007 (36.4 percent), 2010 (30.2 percent), 2013 (37.9 percent) but still remains a serious problem that needs further treatment. If the trend of stunting problems continues, an estimated 127 million toddlers will be stunted by 2025[1, 2].

In 2012, through the World Health Assembly Resolution 65.6, a comprehensive effort on the nutritional condition of mothers, infants and children, known as the "six global nutrition targets for 2025" was recommended. This policy concerns the first target of a 40 percent reduction in the number of children under-five who are stunted[2]. Nutritional interventions alone (specific programs) are not sufficient to achieve optimal child development and nutrition, as it is important to strengthen sensitive nutrition development efforts and improve them with evidence-based, nationwide multi-sectoral plans aimed at stunting, combining nutritional interventions with health, family planning, water and sanitation strategies and other factors that influence the stunting risk (sensitive programs). It takes a measurable work plan to develop and oversee the implementation of commitments and targets[1, 17].

\section{Early initiation to breastfeeding and stunting}

This study shows that children who do not get an early initiation to breastfeeding are 1.3 times more likely to be stunted than those who are breastfed early. These results illustrate early initiation to breastfeeding as a form of maternal care and the best giving of nutrients early in life that can reduce the risk of stunting. Early breastfeeding initiation is one of the entrances to successful breastfeeding at a later time and ensures children receive appropriate nutritional intake[2, 7].

Similar results are proven in previous studies. Initiation of breastfeeding after six hours of birth or discarding colostrum due to ignorance of its health benefits as well as breastfeeding supplementation is a risk factor for stunting children under five[18]. This study shows that one of the efforts to overcome stunted problems in children is to provide early initiation to breastfeeding. Early initiation to breastfeeding takes place naturally, where the child after birth is directly placed in the mother's chest to initiate the search for the mother's nipple to feed within the first hour of birth. Early initiation to breastfeeding is 


\begin{tabular}{|c|c|c|c|c|c|c|c|c|c|}
\hline \multirow{2}{*}{ Variables } & \multicolumn{4}{|c|}{ Children 6-59 months } & \multirow{2}{*}{$\begin{array}{c}\text { Crude } \\
\text { OR }\end{array}$} & \multirow{2}{*}{\multicolumn{2}{|c|}{$95 \% \mathrm{CI}$}} & \multirow[b]{2}{*}{$p$-value } & \multirow{3}{*}{$\begin{array}{r}\text { initiation to } \\
\text { breastfeeding }\end{array}$} \\
\hline & \multicolumn{2}{|c|}{ Normal } & \multicolumn{2}{|c|}{ Stunting } & & & & & \\
\hline \multirow{2}{*}{\multicolumn{10}{|c|}{$\begin{array}{l}\text { Early initiation to breastfeeding } \\
\text { Yes }\end{array}$}} \\
\hline & & & & & & & & & \\
\hline & 933 & 68.9 & 421 & 31.1 & 1.5 & 1.2 & 1.8 & $0.000 * *$ & \\
\hline \multicolumn{9}{|l|}{ Visiting community base heath service } & 38 \\
\hline $\begin{array}{l}\text { Good }(\geqslant 4 \text { times in } 6 \text { month }) \\
\text { Not good ( }<4 \text { times in } 6 \text { month) }\end{array}$ & $\begin{array}{r}1,105 \\
709\end{array}$ & $\begin{array}{l}74.2 \\
70.1\end{array}$ & $\begin{array}{l}385 \\
303\end{array}$ & $\begin{array}{l}25.8 \\
29.9\end{array}$ & $\begin{array}{l}1 \\
1.2\end{array}$ & $\begin{array}{l}\text { Ref } \\
1.0\end{array}$ & 1.5 & $0.044^{* *}$ & \\
\hline \multicolumn{10}{|l|}{ Birth weight } \\
\hline Normal ( $\geqslant 2,500$ gram $)$ & 1,764 & 73.0 & 653 & 27.0 & 1 & Ref & & & \\
\hline Low birth weight ( $<2,500$ gram) & 50 & 58.8 & 35 & 41.2 & 1.9 & 1.1 & 3.2 & $0.018^{* *}$ & \\
\hline \multicolumn{10}{|l|}{ Length at birth } \\
\hline Less $(<48 \mathrm{~cm})$ & 465 & 69.4 & 205 & 29.5 & 1.2 & 0.9 & 1.5 & $0.052^{*}$ & \\
\hline \multicolumn{10}{|l|}{ Exclusive breastfeeding } \\
\hline & 727 & 70.6 & 302 & 29.4 & 1.2 & 0.9 & 1.4 & $0.104^{*}$ & \\
\hline \multicolumn{10}{|l|}{ Diarrhea history in the last 1 month } \\
\hline & 1,566 & 73.6 & 563 & 26.4 & 1 & Ref & & & \\
\hline Yes & 248 & 66.6 & 125 & 33.4 & 1.4 & 1.1 & 1.7 & $0.007 * *$ & \\
\hline \multicolumn{4}{|l|}{ Cough history in previous month } & 27.1 & 1 & Ref & & & \\
\hline Yes & 686 & 71.8 & 269 & 28.2 & 1.1 & 0.9 & 1.3 & 0.590 & \\
\hline & & \\
\hline Yes & 817 & 71.9 & 319 & 24.9 & 1.1 & 0.9 & 1.3 & 0.560 & \\
\hline \multicolumn{10}{|l|}{ Fever history in previous month } \\
\hline Yes & 628 & 70.9 & 257 & 29.1 & 1.1 & 0.9 & 1.4 & $0.231 *$ & \\
\hline \multicolumn{10}{|c|}{ Shortness of breath history in previous month } \\
\hline & 1,758 & 72.5 & 668 & 27.5 & 1 & Ref & & & \\
\hline Yes & 56 & 73.8 & 20 & 26.2 & 0.9 & 0.6 & 1.5 & 0.790 & \\
\hline \multicolumn{10}{|l|}{ Boiling drinking water } \\
\hline Yes & 1,565 & 71.9 & 612 & 28.1 & 1 & Ref & & & \\
\hline No & 250 & 76.7 & 75 & 23.3 & 0.7 & 0.5 & 1.1 & $0.119 *$ & \\
\hline \multicolumn{10}{|l|}{ House structure } \\
\hline Good & 1,766 & 72.9 & 657 & 27.1 & 1 & Ref & & & \\
\hline Not good & 48 & 61.0 & 31 & 39.0 & 1.7 & 1.1 & 2.6 & $0.013^{* *}$ & \\
\hline \multicolumn{10}{|l|}{ Sanitation facilities } \\
\hline & 1,587 & 73.7 & 565 & 26.3 & 15 & Ref & 20 & $0003 * *$ & \\
\hline \multirow{2}{*}{\multicolumn{10}{|c|}{ Water sources }} \\
\hline & & & & & & & & & \\
\hline $\begin{array}{l}\text { Pipe } \\
\text { Well }\end{array}$ & 362 & 71.4 & 144 & 28.6 & 1 & Ref & & & $\begin{array}{l}\text { Table } 1 . \\
\text { Bivariate }\end{array}$ \\
\hline Well & 1,031 & 72.3 & 395 & 27.7 & 0.9 & 0.7 & 1.2 & 0.741 & $\begin{array}{l}\text { Bivariate analysis } \\
\text { early initiation to }\end{array}$ \\
\hline $\begin{array}{l}\text { River } \\
\text { Rainwater collection }\end{array}$ & 26 & 45.3 & 31 & 54.7 & 3.0 & 1.5 & 5.9 & $0.001^{* *}$ & earty initiation to \\
\hline Rainwater collection & 113 & 83.2 & 23 & 16.8 & 0.5 & 0.3 & 0.9 & $0.025^{* *}$ & breastfeeding relations \\
\hline \multirow[t]{3}{*}{ Gallon refill } & 283 & 75.1 & 94 & 24.9 & 0.8 & 0.6 & 1.2 & 0.299 & and other \\
\hline & & & & & & & & & stunting in children \\
\hline & & & & & & & & ntinued) & $6-59$ months \\
\hline
\end{tabular}


Variables

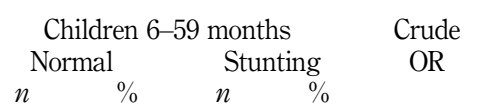

$95 \% \mathrm{CI} \quad p$-value

Quality of water source

Good

Not good

1,77

Number of household members

Small ( $\leqslant 4$ persons)

Big ( $>4$ persons)

$\begin{array}{rrrrllll}39 & 63.5 & 23 & 36.5 & 1.5 & 0.9 & 2.6 & 0.109^{*} \\ & & & & & & & \\ 1,494 & 73.0 & 552 & 27.0 & 1 & \text { Ref } & & \\ 321 & 70.4 & 135 & 29.6 & 1.1 & 0.9 & 1.4 & 0.294 \\ & & & & & & & \\ 497 & 77.4 & 145 & 22.6 & 1 & \text { Ref } & & \\ 1,318 & 70.8 & 542 & 29.2 & 1.4 & 1.1 & 1.8 & 0.011^{* *}\end{array}$

Region type

Urban

Rural

.

Father and mother ethnicity

Origin

796

Mixed ethnic

Outsider ethnic

230

66.7

397

\section{3.}

788

Fathers education

Medium (high school or above)

Basic (Junior high school or not)

$\begin{array}{llllllll}878 & 74.3 & 303 & 25.7 & 1 & \text { Ref } & & \\ 937 & 70.9 & 384 & 29.1 & 1.2 & 0.9 & 1.4 & 0.087^{*}\end{array}$

Mothers education

Medium (high school or above)

Basic (Junior high school or not)

849

$849 \quad 75.1$

$75.1 \quad 282$

Father's occupation

Fixed work

Labor and others

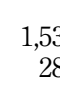

1,53

70.4

Mothers occupation

Housewife

Career

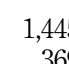

$72.2 \quad 589$

406

24.9

29.6

$\begin{array}{ll}1 & \text { Ref } \\ 1.3 & 1.0\end{array}$

$1.60 .023^{* *}$

Age (months)

6-11

12-23

24-59

Sex

Boys

$\begin{array}{llll}928 & 71.4 & 373 & 28.6 \\ 886 & 73.8 & 315 & 26.2\end{array}$

27.8
26.0

1 Ref

$0.9 \quad$ Ref

$1.2 \quad 0.517$

Girls

Table I.

Notes: $n=2,502$. Ref, reference. $* p<0.25 ; * * p<0.05$

535

27.0

$\begin{array}{llll}1 & \text { Ref } & & \\ 1.1 & 0.9 & 1.4 & 0.357\end{array}$

easy, takes a short time and has a long-term effect on the child. This opportunity can be accomplished if the mother of the newborn is aware of the benefit and process of early breastfeeding. Promotion efforts to educate the mother and family should be carried out before birth.

Other results of the analysis showed a significant association between age, water source and birth weights to stunting in 6-59 months of children. These results indicate that stunting is caused by many factors.

Early initiation to breastfeeding ensures that the baby gets colostrum that increases the child's immunity to infection and furthermore, exclusive breastfeeding will keep children away from contaminated water sources for at least the first 6 months. Adequate foods and no infection make the child grow optimally[19-22] and reduces the risk of stunting. 


\begin{tabular}{|c|c|c|c|c|c|c|c|}
\hline \multirow{2}{*}{$\frac{\text { No. }}{1}$} & \multirow{2}{*}{$\begin{array}{l}\text { Variables } \\
\text { No early initiation to breastfeeding }\end{array}$} & \multirow{2}{*}{$\frac{B}{0.241}$} & \multirow{2}{*}{$\frac{p \text {-value }}{0.024}$} & \multirow{2}{*}{$\frac{\text { Adjusted OR }}{1.3}$} & \multicolumn{2}{|c|}{$95 \% \mathrm{CI}$} & \multirow{2}{*}{$\begin{array}{r}\text { Early } \\
\text { initiation to } \\
\text { breastfeeding }\end{array}$} \\
\hline & & & & & 1.0 & 1.6 & \\
\hline 2 & Birth weight $(<2,500 \mathrm{gms})$ & 0.695 & 0.011 & 2.0 & 1.2 & 3.4 & \\
\hline 3 & Diarrhoea & 0.317 & 0.016 & 1.4 & 1.1 & 1.8 & \\
\hline 4 & House structure (not good) & 0.456 & 0.047 & 1.6 & 1.0 & 2.5 & \\
\hline \multirow[t]{6}{*}{5} & \multicolumn{6}{|l|}{ Water sources } & \\
\hline & Pipe & & & 1 & Ref & & 9 \\
\hline & Well & -0.018 & 0.895 & 1.0 & 0.7 & 1.3 & \\
\hline & River & 0.759 & 0.032 & 2.1 & 1.1 & 4.3 & \\
\hline & Rainwater collection & -0.527 & 0.102 & 0.6 & 0.3 & 1.1 & \\
\hline & Gallon refill & -0.067 & 0.710 & 0.9 & 0.6 & 1.3 & \\
\hline 6 & Region type (rural) & 0.301 & 0.031 & 1.4 & 1.0 & 1.8 & \\
\hline \multirow[t]{4}{*}{7} & Father and mother ethnicity & & & & & & \\
\hline & Origin & & & 1 & Ref & & \\
\hline & Mixed ethnic & -0.522 & 0.004 & 0.6 & 0.4 & 0.8 & \\
\hline & Outsider ethnic & -0.385 & 0.001 & 0.7 & 0.5 & 0.9 & \\
\hline \multirow[t]{4}{*}{8} & Age (months) & & & & & & \\
\hline & $6-11$ & & & 1 & Ref & & Multivariate analysis \\
\hline & $12-23$ & 0.604 & 0.000 & 1.8 & 1.3 & 2.6 & early initiation to \\
\hline & $\begin{array}{l}24-59 \\
\text { Jntercent }\end{array}$ & 0.936 & 0.000 & 2.5 & 1.8 & 3.6 & breastfeeding with \\
\hline \multicolumn{7}{|c|}{ Note: Ref, reference } & stunting \\
\hline
\end{tabular}

The difference in risk of stunting based on drinking water sources was also revealed by several other researchers[10,23].

The results of this study indicate that there are differences in the growth of children by age. Growth disorders will accumulate with age[24-27]. Differences in the growth of children by age are also found elsewhere. For two years the age of the child was $9 \mathrm{~cm}$ in contrast to the WHO standard in Malawi, then only increased by $1 \mathrm{~cm}$ by age $2-3$ years from $10 \mathrm{~cm}$ difference. Differences of two centimeters ( 20 percent) occur at birth, $4 \mathrm{~cm}$ (40 percent) occur from birth to 12 months of age, and $3 \mathrm{~cm}$ (30 percent) occur from 12-24 months. Early cause is a combination of growth disorders in the uterus, inadequate nutrition after birth, marked by low exclusive breastfeeding (28 percent) and low nutritional intake of breast milk due to malnourished mother, and infection after birth[27].

\section{Conclusion}

Early initiation to breastfeeding can be associated with preventing stunting in 6-59 month of children after adjusted to all others variables. There is also a significant association between water source and birth weight to stunting. Children with a low birth weight are 2.0 times at higher risk of stunting than normal-born. The most dominant risk factor for stunting was age 24-59 months with a risk 2.5 times higher than the age of 6-11 months. Early initiation to breastfeeding is easy and has a long-term positive health benefit on the child.

\section{Recommendations}

Promoting breast feeding benefits to mothers should begin before birth. Support from health personnel, especially officers who assist the birth process, should be increased.

It is important to reinforce the importance of early initiation to breastfeeding and clean drinking water sources as a prevention to stunting. Improvement of drinking water sources by replacing contaminated river water with clean pipe water should be practiced. Finally, it is important to introduce additional and more regular educational programs for pregnant women about how to prevent low birth weight in babies together with clear information on the benefits of early breastfeeding. 
JHR

32,5

340

\section{References}

1. Black RE, Victora CG, Walker SP, Bhutta ZA, Christian P, de Onis M, et al. Maternal and child undernutrition and overweight in low-income and middle-income countries. Lancet. 2013 Aug; 382 (9890): 427-51. doi: 10.1016/s0140-6736(13)60937-x

2. World Health Organization [WHO]. Global Nutrition Targets 2025: Stunting Policy Brief. WHO/NMH/NHD/143. Geneva: WHO; 2014.

3. Ministry of Health. Basic Health Research. Jakarta: Ministry of Health Republic Indonesia; 2007.

4. Ministry of Health. Basic Health Research. Jakarta: Ministry of Health Republic Indonesia; 2010.

5. Ministry of Health. Basic Health Research. Jakarta: Ministry of Health Republic Indonesia; 2013.

6. Paiva M, Souza TO, Canon F, Perot C, Xavier LC, Ferraz KM, et al. Stunting delays maturation of triceps surae mechanical properties and motor performance in prepubertal children. Eur J Appl Physiol. 2012 Dec; 112(12): 4053-61. doi: 10.1007/s00421-012-2387-8

7. Black RE, Allen LH, Bhutta ZA, Caulfield LE, de Onis M, Ezzati M, et al. Maternal and child undernutrition: global and regional exposures and health consequences. Lancet. 2008 Jan; 371 (9608): 243-60. doi: 10.1016/s0140-6736(07)61690-0

8. Checkley W, Buckley G, Gilman RH, Assis AM, Guerrant RL, Morris SS, et al. Multi-country analysis of the effects of diarrhoea on childhood stunting. Int J Epidemiol. 2008 Aug; 37(4): 816-30. doi: 10.1093/ije/dyn099

9. Dharmage SC, Rajapaksa LC, Fernando DN Risk factors of acute lower respiratory tract infections in children under five years of age. Southeast Asian J Trop Med Public Health. 1996 Mar; 27(1): 107-10.

10. Chirande L, Charwe D, Mbwana H, Victor R, Kimboka S, Issaka AI, et al. Determinants of stunting and severe stunting among under-fives in Tanzania: evidence from the 2010 cross-sectional household survey. BMC Pediatr. 2015 Oct; 15: 165. doi: 10.1186/s12887-015-0482-9

11. Wamani H, Astrom AN, Peterson S, Tumwine JK, Tylleskar T. Predictors of poor anthropometric status among children under 2 years of age in rural Uganda. Public Health Nutr. 2006 May; 9(3): 320-6.

12. Rah JH, Cronin AA, Badgaiyan B, Aguayo VM, Coates S, Ahmed S. Household sanitation and personal hygiene practices are associated with child stunting in rural India: a cross-sectional analysis of surveys. BMJ Open. 2015 Feb; 5(2): e005180. doi: 10.1136/bmjopen-2014-005180

13. Reyes H, Perez-Cuevas R, Sandoval A, Castillo R, Santos JI, Doubova SV, et al. The family as a determinant of stunting in children living in conditions of extreme poverty: a case-control study. BMC Public Health. 2004 Nov; 4: 57. doi: 10.1186/1471-2458-4-57

14. Dhatrak PP, Pitale S, Kasturwar NB, Nayse J, Relwani N. Revalence and epidemiological determinants of malnutrition among under-fives in an urban slum, Nagpur. National Journal of Community Medicine. 2013; 4(1): 91-5.

15. Fikadu T, Assegid S, Dube L. Factors associated with stunting among children of age 24 to 59 months in Meskan district, Gurage Zone, South Ethiopia: a case-control study. BMC Public Health. 2014 Aug; 14: 800. doi: 10.1186/1471-2458-14-800

16. Gordon NH, Halileh S. An analysis of cross sectional survey data of stunting among Palestinian children less than five years of age. Matern Child Health J. 2013 Sep; 17(7): 1288-96. doi: 10.1007/ s10995-012-1126-4

17. de Onis M, Dewey KG, Borghi E, Onyango AW, Blossner M, Daelmans B, et al. The world health organization's global target for reducing childhood stunting by 2025: rationale and proposed actions. Matern Child Nutr. 2013 Sep; 9(S2): 6-26. doi: 10.1111/mcn.12075

18. Kumar D, Goel NK, Mittal PC, Misra P. Influence of infant-feeding practices on nutritional status of under-five children. Indian J Pediatr. 2006 May; 73(5): 417-21.

19. Kramer MS, Guo T, Platt RW, Sevkovskaya Z, Dzikovich I, Collet JP, et al. Infant growth and health outcomes associated with 3 compared with 6 mo of exclusive breastfeeding. Am J Clin Nutr. 2003 Aug; 78(2): 291-5. doi: 10.1093/ajcn/78.2.291

20. Brown JE Nutrition Through the Life Cycle. Belmont, CA: Thomson/Wadsworth; 2005. 
21. Permatasari TAE, Syafruddin A. Early initiation of breastfeeding related to exclusive breastfeeding and breastfeeding duration in rural and urban areas in Subang, West Java, Indonesia. J Health Res. 2016; 30(5): 337-45.

22. Huuhtanen S, Laukkanen A.A. Guide to Sanitation Andhygiene for Those Working in Developing Countries. Tampere: Tampere University of Applied Sciences, TAMK; 2006.

23. Oktarina Z, Sudiarti T. Risk factors stunting in toddlers (24-59 months) in Sumatra. Jurnal Gizi dan Pangan. 2013; 8(3): 175-80.

24. Darteh EK, Acquah E, Kumi-Kyereme A. Correlates of stunting among children in Ghana. BMC Public Health. 2014 May; 14: 504. doi: 10.1186/1471-2458-14-504

25. Hien NN, Hoa NN Nutritional status and determinants of malnutrition in children under three years of age in Nghean, Vietnam. Pak J Nutr. 2009; 8(7): 958-64.

26. Zottarelli LK, Sunil TS, Rajaram S. Influence of parental and socioeconomic factors on stunting in children under 5 years in Egypt. East Mediterr Health J. 2007 Nov-Dec; 13(6): 1330-42.

27. Dewey KG, Huffman SL. Maternal, infant, and young child nutrition: combining efforts to maximize impacts on child growth and micronutrient status. Food Nutr Bull. 2009 Jun; 30(S2): S187-9. doi: $10.1177 / 15648265090302$ s201

\section{Corresponding author}

Muldiasman can be contacted at: rajomudojr@gmail.com

For instructions on how to order reprints of this article, please visit our website: 